\title{
INVESTIGATIONS INTO PERIPHERAL CIRCULATORY AND METABOLIC PHENOMENA* ON THE "REDUCTION TIME" OF THE BLOOD OF THE SKIN AND ITS RELATION TO THE BASAL METABOLISM OF THE ORGANISM
}

\author{
BY \\ EJNAR JARLØV and NIELS V. JARLØV \\ Copenhagen
}

The campaign against a widespread disease often makes apparently insuperable demands on the strategic power of the combatants, chiefly because their knowledge of the enemy is insufficient. Man has repeatedly given up this struggle because the problem seemed insoluble but, from time to time, tenacious energy has been rewarded with success and has brought a solution, or at any rate a rapid advance towards one. For instance, in the half-century since the discovery of the tubercle bacillus, the lethal power of tuberculosis had been reduced to less than one-tenth; this result was achieved before we had succeeded in finding a certain remedy for the disease, by close examination of its nature and mode of action, and thus we have managed to create a scientifically well-founded rational prophylaxis-which is the ideal procedure.

The study of the aetiology and pathogenesis of the rheumatic diseases is now the principal task of rheumatological research. At present we are confronted with a group of disorders which bear a close resemblance to a large and complicated jig-saw puzzle in which some of the pieces have already been put in their proper places, others are at our disposal, but unplaced, and others again are entirely missing. As a consequence of recent research, the study of the peripheral vascular system will become of importance in the study of the rheumatic diseases (van Breemen, Dautrebande, Laignel-Lavastine, Pemberton). Otto Meyer considers that infectious foci give rise to considerable functional disturbances of the large vessels, and he draws attention to Bauer's results which show that in the rheumatic articular affections histological changes occur in the numerous fine vessels of the synovial membranes.

The nature of these changes has not been fully explained. Among other things it has not been settled whether they are primary vascular changes or whether they are secondary in relation to changes of the vegetative nervous system, its peripheral or central parts. Considering that thought is tending away from Virchow's cellular

* Read in summary before the Seventh International Congress on Rheumatic Diseases, New York, June 1, 1949. 
pathology and towards Ricker-Speransky's neural pathology, it can at any rate be taken for granted that the study of the anatomy, physiology, and pathology of the peripheral vessels will render possible the employment of the phenomena of peripheral circulation and metabolism as indicators of the condition of the entire vegetative system and its role in the local processes. The solution of this problem will not, of course, lead to the solution of the rheumatic problem, but it is highly probable that this solution represents a missing piece-and a very important one-in the jig-saw puzzle.

The study of the peripheral circulation has been rather stagnant since, more than twenty-five years ago, the Danish Nobel Prize winner, August Krogh, published his famous works on the anatomy and physiology of the capillaries. During the second world war the problem was taken up in different countries and for various reasons but, as conditions were, no co-operation was established until the end of hostilities. A number of different investigators took up the problem for very different motives. No detailed account will be given of the various methods that have been suggested for the examination of the peripheral vascular phenomena, but we shall confine ourselves exclusively to the study of the minutest vessels, even though it must be admitted that a more active physiological importance than has hitherto been imagined must apparently be attributed to the large arteries and veins. It is first and foremost the most peripheral phenomena that are of interest in the study of the rheumatic problem.

With various co-workers we have since 1942 been at work on these problems, and have attempted to elaborate methods for the study of the phenomena of peripheral circulation and metabolism. We have on previous occasions accounted for the so-called digitographic pulse-recording method and also for our electrophotometric pulse recording, which has been considerably improved since one of us (E.J.) became acquainted, during his stay in the U.S.A. in 1946, with the works of Hertzmann and his co-workers, which had not previously been available to us because of Denmark's isolated position during the German occupation.

For peripheral pulse recording we now employ an apparatus which is highly simplified and can be used all over the body (Jarløv and Gravenhorst, 1948). The same apparatus is employed to determine the amount of oxygen given off by the blood in the skin, but such determinations can be made only on extremities where it is possible to induce arterial stasis.

\section{Description of Apparatus}

The apparatus consists of a photo-electric reflectometer (Fig. 1) and a measuring instrument (Cambridge spot-galvanometer) which is provided with a compensation device, enabling the examiner to compensate for the resting potential of the photo-cell and thus to have a "wider galvanometer range" at his disposal, which gives a safer reading. Fig. 1 shows a diagram of the photo-electric galvanometer, which consists of: A, a source of light (a 6-volt bulb); C, a selenium photo-cell ("Eel ", type A) with an opening $9 \mathrm{~mm}$. wide in the central part; B, a sliding filter-holder with red and green filters ("Wratten" gelatine filters, Nos. 29 and 61). When the instrument is placed on the surface of the skin the light rays from the bulb, A, will pass through the filter and be reflected from 
the surface of the skin, $D$, to the side of the photo-cell that is sensitive to light and faces the skin. The electrical impulses of the photo-cell are recorded by means of the

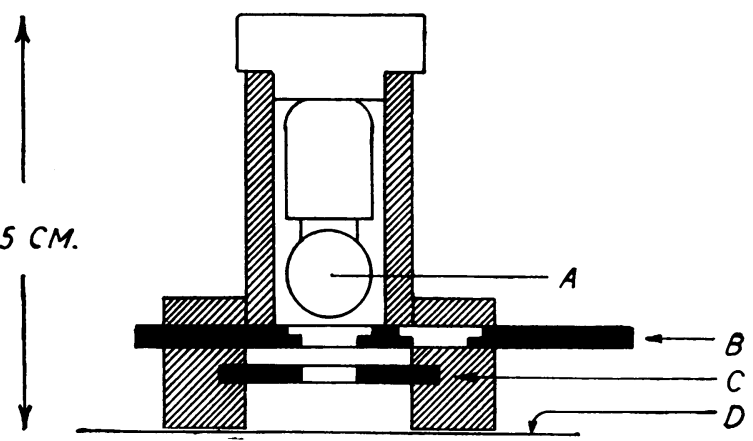

FIG. 1.-Diagram of the photo-electric reflectometer. galvanometer. The filters have been selected with consideration of the differences between the absorption spectra of oxyhaemoglobin and reduced haemoglobin, so that, with the red light, the greatest possible difference of reflection is obtained when the haemoglobin passes from the oxidized state to the reduced state, whereas the reflection of the green light remains uninfluenced by this process (Millikan).

The examination of the reduction of oxyhaemoglobin under arterial compression is

made as follows: the subject is placed in the sitting posture with one upper extremity in the horizontal position at the level of the aortic orifice. The reflectometer is placed in his palm, proximally in the hypothenar region. A sphygmomanometer cuff is applied to the upper arm and sudden and complete arterial compression is produced for about two minutes. If the reflection of red light is determined during this period, a distinct decrease will be observed. After about two minutes' compression the green filter is inserted, and the deflection of the galvanometer will indicate the degree of fullness of blood in the skin, as the reflection of the green light remains uninfluenced by the degree of oxidation of the blood (the haemoglobin), and is influenced only by the amount of blood present in the superficial layers of the skin. The change of reflection for red light during arterial compression is reproduced in Fig. 2 (opposite), where $\mathrm{H}$ expresses the intensity of the reduction of oxyhaemoglobin or, in other words, the oxygen consumption of the tissues of the skin. In addition, $\mathrm{H}$ is influenced by the temperature of the tissues and by the amount of blood present in the skin during the experiment. Immediately before every examination the temperature of the skin is determined thermo-electrically and, as already mentioned, the amount of blood is expressed by means of the reflection of green light, but the ultimate factor of correction to " standard temperature and standard amount of blood" has not not been quite fixed. As will appear from the following, these corrections will be of only minor importance under normal conditions.

So far we have not attempted any determinations on mucous membranes, which, however, should theoretically be possible; it must also be considered possible to employ a similar apparatus in examinations of other organs in animal experiments. Our object is to create methods which can be employed in clinical work, enabling us through clinical examinations to find out what organs are affected, what kind of disturbances are present, what information this will give us, and what are the possibilities of experimental work in a number of different domains, among others in the domain of rheumatology.

By studying for the present the conditions of peripheral circulation and metabolism in the skin we believe we can become informed both of the functions of the organs of circulation and of those of the skin. The examination of the reactions of the peripheral vessels may possibly provide the basis of understanding a number 
of rheumatic problems and, at the same time, through the study of a number of individual reactions to cold, heat, pain, psychic impressions, etc., supply us with

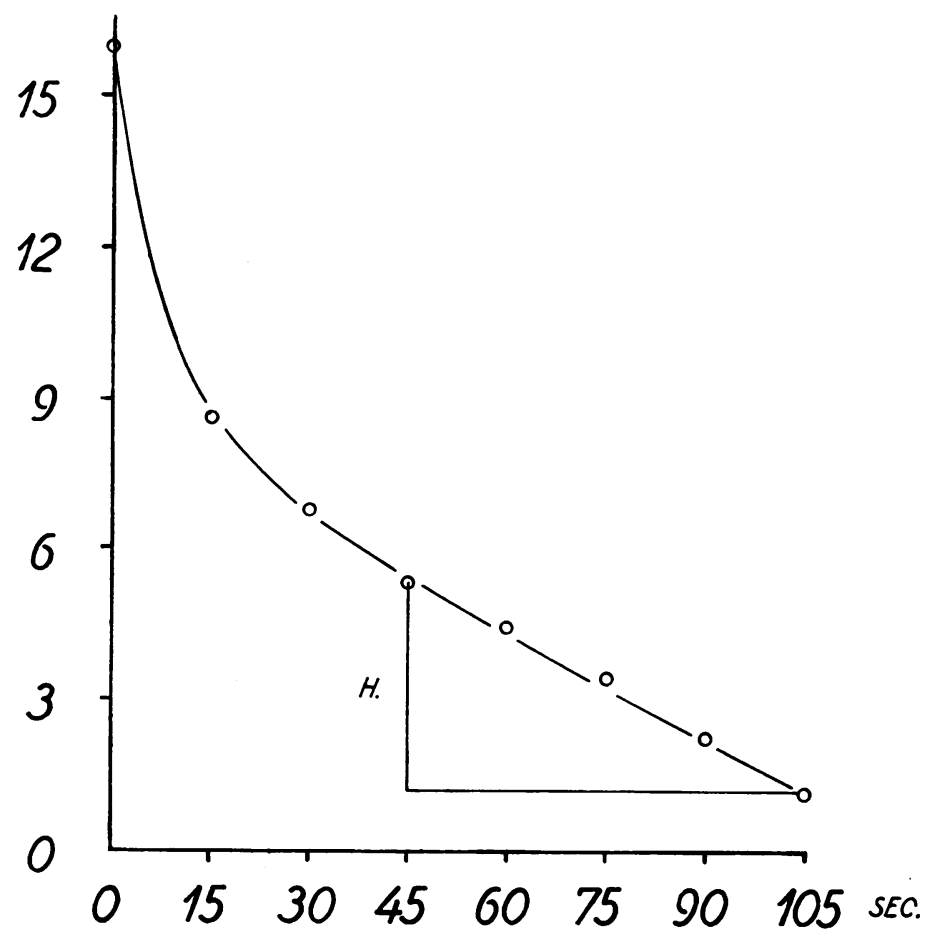

Fig. 2.-Change of reflection for red light during arterial compression.

objective criteria to judge the treatment of the individual case.

At the same time it is highly probable that these examinations may prove an aid to estimating the functional condition of the skin as an organ-a condition to which we attribute much greater importance nowadays than formerly, when the skin was a priori considered to be simply a protective cover over the functioning organs, being only reckoned as a thermo-regulator acting through its circulatory system and its system of sweat glands. It is true that it has been realized for many years that through the "insensible perspiration" the skin also acts as a water-excreting organ. Nowadays, however, many investigators consider that the skin has a series of other functions, among other things that it plays an important role as endocrinous organ and in the formation of antibodies in infections, in particular in the production of diphtheria antitoxin. We shall not deal with modern theories of the function of the skin in fuller detail; the role of the skin in general pathology was recently discussed by P. Robert (1949).

However, it is not the vascular reactions themselves that are important, but the exchange between blood and tissue. As is known, modern functional diagnostic methods have caused determinations of metabolism to be a daily procedure in clinical work, but almost exclusively in the sense of determinations of basal metabolism; so far we have not had any great possibility of estimating clinically the local oxidation processes and the intermediary metabolic processes. It is an attempt in a single field of this domain that we shall describe here, namely the determination of the oxygen consumption of the skin and the relation of this process to the metabolism of the entire organism. We have been working on this problem since 1943, 
but owing to the war and other hindrances we could only follow it up to a small extent until the past few years. Our plan was to determine the reduction of the

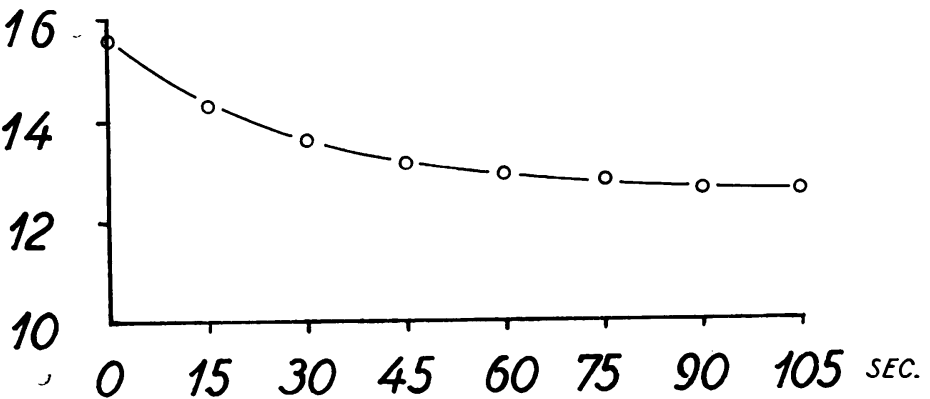

FIG. 3. -The reflection of green light, determined immediately after induction of the complete congestion. blood of the skin by means of its change of colour as observed by electrophotometrical methods during the first few minutes after induction of complete arterial stasis, an idea which was then considered by us

to be quite new; but, when literature became avaitable, it appeared that Ray and others (1946) in America had entertained the same idea and had determined the reduction of the blood spectrometrically. The American investigators stated that through studies of the literature they were surprised to find that the self-same idea had been conceived by Vierordt as early as 1878 .

Vierordt's procedure was briefly as follows: By means of a spectroscope he was able to observe the absorption spectrum of haemoglobin when he studied the skin of a finger under high transillumination. He then interrupted the circulation of the finger by constriction with rubber rings, and determined the time which elapsed before the two characteristic absorption bands of oxyhaemoglobin between the D and E lines disappeared (" the reduction time "). In a subsequent work by Vierordt's pupil, Dennig (1883), the dependence of the reduction time on the temperature of the skin was demonstrated. On the basis of a number of examinations Vierordt, as early as 1878, maintained: " Die Untersuchung des Absorptionsspectrums des in den Gefässen enthaltende Blutes am Lebenden, vor allem am Menschen selbst, verspricht wesentliche Aufschlüsse über die Stärke des jeweiligen Sauerstoffverbrauchs im Körper ...”'

When it is intended to work with such a method we must, as in all other similar examinations, attempt to clear it of sources of error. Among these we have so far reckoned with the following: with a sudden arteriovenous stasis the arterial pressure will fall and the venous pressure will rise, whilst at the same time the conditions of pressure in the capillaries will become abnormal; especially after some time, when the arterial and venous pressures have become equalled, the pressures at the arterial inflow and the venous outflow of the capillaries will be alike, in contrast with the physiological conditions. Thus the results cannot be directly compared with the result of the reduction of the blood in the case of unobstructed flow through the capillaries. The interruption of the circulation, moreover, causes the supply of oxygen to the tissues to decrease abnormally, which after some time must necessarily lead to abnormal conditions of the tissue cells.

The first source of error has been studied by Wilkins and Bradley, who found 
that the difference of pressure was equalized after about 45 seconds, which is in conformity with an observation made by us.

Fig. 3 shows the reflection of green light, determined immediately after induction of the complete congestion; it will be seen here how the amount of blood in the vessels of the skin increases during the first 45 seconds or so, and then remains almost constant during the rest of the examination, in complete conformity with the results of Wilkins and Bradley.

Therefore, we do not consider the changes occurring in the course of the first 45 seconds.

The second source of error hardly plays any great part, as it should be borne in mind that the amount of oxygen given off to the tissues is dependent on the oxygen tension of the plasma, and this will tend to adjust itself by the blood corpuscles giving off more of their oxygen to the plasma. It is not probable that this process will bring about complete compensation, but, owing to the short duration of the experiment, it is hardly possible that any significant error will be involved for this reason.

A third and important source of error is afforded by the natural colour of the skin and the amount of blood present in it. We first determine the latter by measuring the reflection of green light within the wave-lengths about $500 \mu \mu$. For this reflection will be entirely dependent on the amount of blood present in the skin, while the pigmentation, of course, will be the same at the beginning and at the end of the experiment, and, consequently, is of no significance (in this connexion, however, we can only speak of white people without any great abnormal changes of the skin).

As the stasis induced causes a certain reactive hyperaemia, we start the examination with the induction of two or three minutes' complete stasis, and finish every experiment with a determination of the " green rate ", which, with this procedure, is practically the same before and after the determination.

As it appears that the amount of blood present in the skin, the pulsation, and the quantity of oxygen given off vary at different temperatures of the skin, a thermoelectrical determination of the temperature forms an indispensable part of the examination, and a correction for this must be introduced; under normal circumstances this correction plays a very small part, but with extreme values the deviations become very great.

A purely technical source of error may be caused by variations of candle-power. This can be eliminated by inserting a resistance between the source of light and the battery, and by letting the bulb burn for about twenty minutes before the determination begins. Nevertheless, quite slight variations of the candlepower may occur, and therefore we control it before and after every experiment by placing the photo-cells apparatus, with the source of light burning, on a grey dull metal plate and making corrections for the small differences that may appear in the deflection in this control test.

Lastly, there is the question of the experimental conditions under which the metabolism of the skin is to be determined, and this again must be linked up with 
the question of the relation of the metabolism of the skin to that of the rest of the organism. As is known, a certain and very material part of the metabolism of the

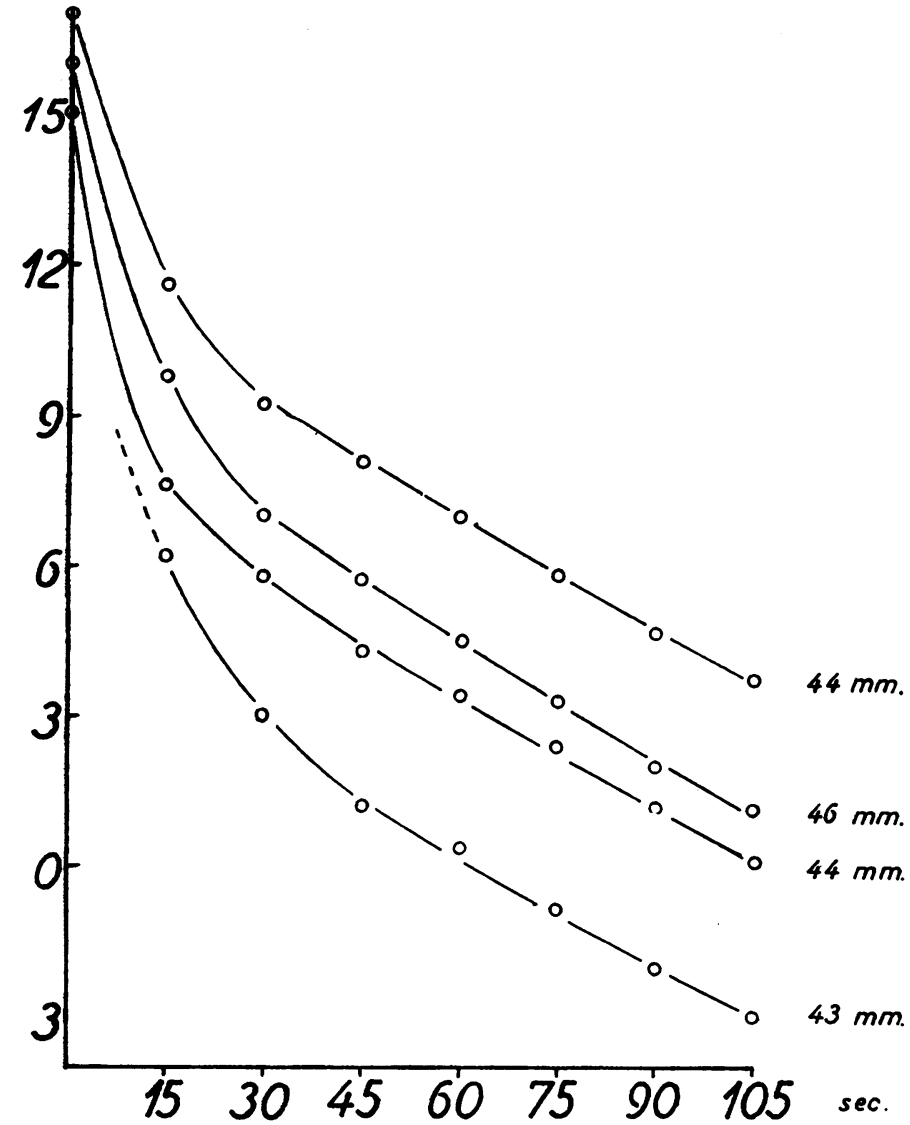

FIG. 4(a).-Metabolism of skin, subject A.

organism is going on in the muscles, which is one of the difficulties with which the determination of the basal metabolism in clinical work is connected, as such a determination requires the patient to be in a state of absolute muscular rest. But this is very difficult to achieve, in particular in nervous individuals, and in many cases, especially in fat people, the work of respiration itself in the recumbent posture will undoubtedly cause the metabolism to be at so high a level that it is not the basal metabolism itself

we determine. The question is, then, how the skin behaves in this respect. It is generally supposed that here the skin is rather passive, and for the present our examinations suggest that the metabolism of the skin in the individual person is strikingly constant when major influences of heat and cold, pain and psychic impressions are avoided. That the last-mentioned influence plays a part appears solely from the fact that Burch of New Orleans and his co-worker, Ray, found that vigorous psychic impressions cause considerable variations in the pulsation of the fine vessels of the skin. Burch, therefore, terms the peripheral vascular system the finest "effector organ " in the psychosomatic processes.

Whilst major influences of the nature mentioned above will thus have to be avoided in these examinations, it seems as if-in contrast with the determinations of metabolism hitherto employed-the muscular work and the ingestion of food play no part in the metabolism of the skin, which we have determined in subjects at 
highly varying distances from meals, and before and after strenuous muscular work, without having been able so far to demonstrate any influence on the metabolism

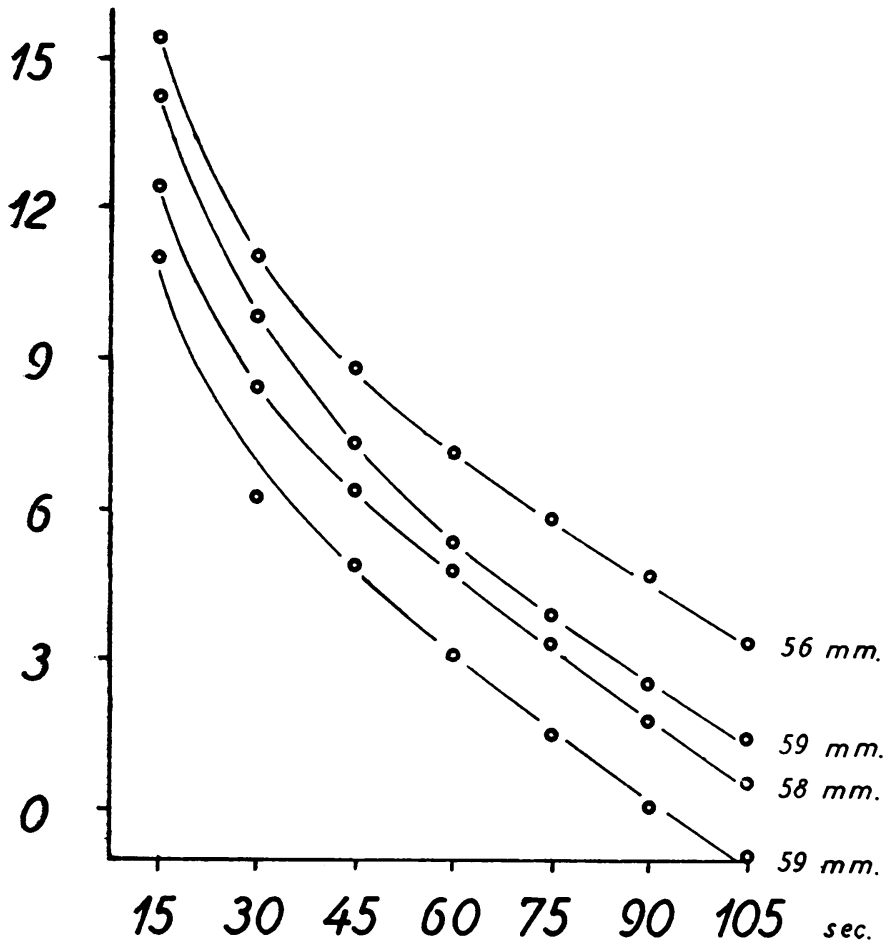

Fig. $4(b)$.-Metabolism of skin, subject B.

of the skin, which remains surprisingly constant in the same individual in determinations under the varying conditions mentioned. Thus, in the course of about six months, we have made a long series of determinations in two persons of different age, always finding the same values in the same person, though the metabolism of the skin of each subject displayed a certain difference one from the other (Figs $4 a$ and $4 b$ ).

In examinations of patients we found similar conditions, but it has not been possible for us to follow them for so long a time. The question is, then, whether this metabolism of the skin is parallel to the basal metabolism of the individuals in question. This was taken for granted in advance by Vierordt when he made his examinations, but apparently he did not realize what sources of error one would have to reckon with. Still, it appeared in our examinations that there is a certain parallelism between the metabolism of the skin and the basal metabolism, as will be seen from the diagrams, which show the " reduction time" of the individuals in question in relation to their basal metabolism as determined by means of Krogh's method. It may be mentioned in this connexion that in hyperthyroid processes there is a decreased reduction time in some cases, but this is not a decrease that is completely parallel to the basal metabolism determined. This may, however, possibly be explained by one case, namely that of a young woman in whom had been found an increase of 38 per cent., whereas our examinations showed a normal reduction time. When the determination was repeated, the basal metabolism was increased by about 20 per cent., and the reduction time was unchanged, but at the third determination the basal metabolism was normal and the reduction time 
remained unchanged. It is probable that the ordinary determination of the basal metabolism in patients with toxic goitre gives too high values because of the nervousness of the patients, and that this phenomenon is reflected to a less degree in the reduction time, but a greater number of examinations will be required to settle this and the question of the relation to the basal metabolism in general.

Having now worked for five years with this technique, we are of opinion that the apparatus has been simplified as much as possible. It has been assembled in such a manner that it is possible in a very short time to record by means of the same apparatus the pulsation of the vessels of the skin, the temperature of the skin, and the reduction time of the blood of the skin. This paves the way for other examinations of the condition of the minutest vessels in a number of different diseases, including the rheumatic diseases, and for an estimate of the importance of the function of the blood vessels to the tissues, and at the same time it renders possible a control of the effect of physio-therapeutical interferences. Further, it is possible that these examinations, which require very little co-operation on the part of the patient and do not cause any inconvenience, may be used as a rapid technique in arriving at an estimate of the basal metabolism in cases where it cannot be determined by means of the usual methods because of anxiety, impaired general health, or the like.

\section{Summary}

The pulsation of the tiniest cutaneous vessels can be registered "digitographically" (that is, plethysmographically) and electrophotometrically.

Our electrophotometric apparatus has been modified for measuring the desoxidation of the blood in the skin capillaries during the first three minutes after establishment of arterial stasis.

By repeated measurings in one individual the "skin metabolism" (after correction in regard to the skin temperature) is found remarkably constant.

The "skin metabolism" on the other hand is different in different individuals. A certain parallelism seems to exist between the "skin metabolism" and the standard metabolism of the organism.

Measurements carried out by this technique may possibly be of importance to rheumatological research, in controlling physiotherapy, and in other fields of physiology and medicine.

\section{REFERENCES}

Dennig, A. (1883). Z. Biol., 19, 483.

Henocque, - , and Nagel, W. (1910). "Handbuch der Physiologie des Menschen". Braunsweig (Ergänzungsband).

Jarløv, E., Hansen, K. G., Ottosen, M., and Wegener, C. F. (1946). Finseninstitutets Jubilaeumsskrift, 380. København.

—, and Jarløv, N. V. (1948). Studia et Opuscula in Honorem Einar Meulengracht, 221. Copenhagen.

Jarløv, N. V., and Gravenhorst, J. S. (1948). Nord. Med., 40, 2422.

Krogh, A. (1922). Wien. klin. Wschr., 35, 290.

(1923). Boston med. surg. J., 189, 313.

(1924). “Anatomie und Physiologie der Capillaren". Berlin; also translation, "The Anatomy and Physiology of the Capillaries", New Haven, 1929. 
Matthes, K. (1934). Arch. exp. Path. Pharm., 176, 683.

—, and Gross, F. (1939). Ibid., 191, 369.

- - (1939). Ibid., 191, 381.

- - (1939). Ibid., 191, 391.

Ray, G. B., Johnson, J. R., and Ray, L. H. (1946). Amer. J. Physiol., 147, 636.

- , Ray, L. H., and Johnson, J. R. (1946). Ibid., 147, 630.

Robert, P. (1949). Schweiz. med. Wschr., 79/14, 309.

Vierordt, K. (1878). Z. Biol., 14, 422.

Wilkins, R. W., and Bradley, S. E. (1946). Amer. J. Physiol., 147, 260.

\section{Les Phénomènes Circulatoires Périphérales et Métaboliques}

RÉSUMÉ

La pulsation des plus petits vaisseaux peut être enregistrée en manière digitographique (c'est à dire, pléthysmographique) et électrophotométrique.

Notre appareil électrophotométrique a été modifié pour la mesure de la désoxydation du sang aux capillaires cutanés pendant les trois premières minutes après l'établissement de stase artérielle.

Par une série d'expériences sur le même sujet " le métabolisme cutané " (correction faite pour la température de la peau) s'est trouvé être singulièrement invariable.

Par contre le "métabolisme cutané " varie d'un sujet à l'autre. Il paraît être un certain parallélisme entre le " métabolisme cutané " et le métabolisme basal de l'organisme.

Peut-être des mesures faites par cette méthode seront-elles d'importance pour les recherches rhumatologiques, pour le contrôle de la physio-thérapie, et dans d'áutres domaines de la physiologie et de la médecine.

\section{Los Fenomenos de la Circulación Periferale y los Fenomenos Metabolicos}

\section{RESUMEN}

Las pulsaciones de los vasos cutáneos más diminutos pueden registrarse " digitográficamente " (es decir pletismográficamente) y electrofotométricamente.

Nuestro aparato electrofotométrico ha sido modificado para que pueda medir la desoxidación de la sangre en los capilares del cutis durante los tres primeros minutos posteriores al establecimiento del estasis arterial.

Repetidas medidas tomadas en un mismo individuo han mostrado que el " metabolismo cutáneo ", después de haberlo corregido en relación con la temperatura de la piel, es notablemente constante.

Por otro lado el metabolismo cutaneo es diferente en los diferentes individuos. Parece que existe cierto paralelismo entre el "metabolismo cutáneo" y el metabolismo básico del organismo.

Es posible que las medidas hechas por este procedimiento puedan asistir considerablemente en los trabajos de investigación reumatológica y en el control de la fisioterapia, así como en otras esferas de la fisiología y de la medicina. 